Vol. 07, No. 02, pp. 130-144, June 2014

\title{
FURNACE BRAZING OF OXYGEN FREE HIGH CONDUCTIVITY COPPER TO SILICON STEEL
}

\author{
Omar Saad Salih \\ Assistant lecturer, Technical College-Baghdad, Iraq \\ E-mail: omar_s_salih@yahoo.com \\ (Received: 17/6/2013; Accepted: 15/9/2013)
}

\begin{abstract}
Furnace brazing was carried out to produce joints between two different materials, Oxygen Free High Conductivity Copper [OFHC] type ISO C10300 and silicon steel (electric steel) type ASTM 36F145 by using two groups of filler metals were selected in this research, silver group type DIN L-Ag20Cd and copper group type AWS BCuP-1 with using flux type AWS FB3-A to remove oxide and protect the welding joint.

The brazing temperature for both filler was $790^{\circ} \mathrm{C}$ and $940^{\circ} \mathrm{C}$ respectively above liquidus temperature of them, then soaking at different time $(10,20,30,40,50$, and $60 \mathrm{~min}$.) for each filler metal. The microstructures of cross section area of joints were revealed in optical microscope shows presence of different reaction in the brazed area.

The maximum double shear strength of dissimilar brazed joints was $47 \mathrm{MPa}$ by using filler metal AWS BCuP-1 at 30min. soaking time, while using filler metal DIN L-Ag20Cd give rice in double shear strength to $98 \mathrm{MPa}$ at $30 \mathrm{~min}$. soaking time due to better coalescence of the mating surfaces .The occurrence of solid solution and different types of intermetallic compounds such as $\mathrm{Cu}_{5} \mathrm{Si}, \mathrm{Fe}_{3} \mathrm{Zn}_{10}, \mathrm{FeZn}_{10}, \mathrm{Cu}_{5} \mathrm{Zn}_{6}, \mathrm{CuZn}, \mathrm{CdCu}_{2}, \mathrm{Cd}_{3} \mathrm{Cd}_{4}, \mathrm{Cd}_{3} \mathrm{Cu}, \mathrm{Cu}_{3} \mathrm{P}$, and $\alpha$-Fe that is responsible for joint strength has been detected by X-ray diffraction inspection.
\end{abstract}

Keywords: Furnace brazing, OFHC, Silicon steel, Shear strength, Intermetallic compounds.

\section{1- INTRODUCTION}

In recent years, interest has grown in the joining of dissimilar metal combinations in the automotive and aerospace industries. Brazing is important industrial methods of bonding ferrous metals to non-ferrous metals, and for bonding metals having very different melting temperatures and it is especially widely used in connection with mass production. They have their given applications in connection with particular materials and components, for which welding are unsuitable due to the considerably higher temperatures and limited abilities to bond different metals. ${ }^{[1,2]}$ 
The coalescence is produced by using a ferrous or nonferrous filler metal that must have a liquidus temperature above $450^{\circ} \mathrm{C}$ and below the solidus temperature of the base metal. The filler material is necessarily of a different composition than the base materials and it is distributed between close-fitting surfaces of the joint typically $(0.025-0.25 \mathrm{~mm})$ by capillary action which plays a major role in filler flow through the joint, while surface wetting plays a major role in the filler's spreading. Chemical bonds were formed between the filler material and the base materials, substantial diffusion of elements in the filler into the base material, and vice versa, almost occur. ${ }^{[3,4]}$

A sound brazed joint generally results when an appropriate filler alloy is selected, surface cleanliness, metal and flux inclusions, different melting temperatures of the components, cooling rate of the joint, excessive alloying of the brazing metal, improper joint design, and tolerances. ${ }^{[5]}$

Furnace brazing is joining process use in the aerospace and other industries to produce strong permanent and hermetic structural joints. It is used exclusively where the parts to be brazed can be assembled with the filler material in the form of wire, foil, filings, slugs, shims, powder, paste, and tape preplaced in or near the joints. Fluxing is used except when an atmosphere is specifically introduced into the furnace to perform the same shielding gas. Furnaces are either batch or continuous types with possibly atmosphere controls, and should have automatic time and temperature. ${ }^{[4,6]}$

Special combinations of copper and its alloys allow wide range of diverse applications in various fields such as architecture, aerospace, electrical engineering, communications, automotive, and solar energy systems because of its favorable properties which include high electrical and thermal conductivity, high resistance to corrosion, and easy processing. Oxygen-free coppers C10100 and C10200 are particularly suitable for applications requiring high electrical conductivity coupled with exceptional ductility, low gas permeability, freedom from hydrogen embrittlement. Although conventional fusion welding methods can be used for joining of copper and its alloys but it is usually difficult due to their high thermal conductivity. ${ }^{[5,7,8,9]}$

The copper phosphor family BCuP and silver alloy family especially BAg-1 filler metals of brazing are widely recommended for joining copper and high-copper alloys. The BAg-1 filler is generally recognized as being the lowest-melting-point silver brazing alloy. ${ }^{[3,10]}$

Steel and its alloys represent the most important and widely used materials in industrial applications. Gradually, composite structures of dissimilar metals were accepted in national defense and civil industrial fields, such as aeronautics and astronautics, and electric power 
industries. Filler metals type $\mathrm{BAg}, \mathrm{BCu}$ series, and $\mathrm{RBCuZn}$ are the most common filler metals used for the brazing of carbon steels. ${ }^{[3,11,12]}$

\section{2- EXPERIMENTAL PROCEDURE}

The base metals used in this work were plate of oxygen free high conductivity copper ISO C10300 used in busbars and sheet of silicon steel ASTM 36F145 having $10 \mathrm{~mm}$ and $1 \mathrm{~mm}$ in thickness respectively. The chemical compositions of the base metals are presented in (Table-1) and (Table-2) ${ }^{[9,13]}$. The copper was cut into 20x18x10 mm and steel sheet specimens were cut into $20 \times 18 \times 1 \mathrm{~mm}$ for double shear strength and microstructure testing. The copper oxide film is removed by grinding the surfaces using emery papers ASTM grit 800 then immersion the specimens in a solution consist of $5 \%$ dichromate alpotassium, $10 \%$ sulpheric acid, and $85 \%$ water for $15 \mathrm{~min}$. to precipitate layer on the surface to protect it from oxidization during brazing process and finely wash it with water then alcohol and dry it. While the oxide film and contaminations on steel specimens were removed by immersion in hydrochloric acid $(\mathrm{HCl})$ for $10 \mathrm{~min}$.

The filler metals were used for brazing DIN L-Ag20Cd and AWS BCuP-1 both of them in form of wire which were cool rolled to a foil of $150 \pm 5 \mu \mathrm{m}$ in thickness. The chemical compositions for both filler metals are given in (Table-3) ${ }^{[14,15]}$. Flux type AWS FB3-A dissolved in distilled water was used. Brazing was done with electrical muffle furnace and the specimen temperature was measured by K-type thermocouple having $\pm 1^{\circ} \mathrm{C}$ installed to touch the sample as close as possible to the joining interfaces.

The brazing procedure used in this work done by fluxing the specimens firstly and sandwiched filler foil between steel and copper specimens (Figure-1)and fixing it by use fixtures made from steel 100x100x10 mm with four M16 stainless steel bolts, torque spin used to apply uniform compression force on these bolt then put the assembly in furnace and heats it to brazing temperature of filler metals $940^{\circ} \mathrm{C}$ and $790^{\circ} \mathrm{C}$ for AWS BCuP-1 and DIN L-Ag20Cd respectively then soaking at these temperature for different time $(10,20,30$, 40, 50, and $60 \mathrm{~min}$.) later leave specimens in furnace to slow cooling .

The metallographic specimens (one sample for each condition) were prepared by grinding with emery paper ASTM grit 240, 400, 600, 800, 1000, 1200, and 2000 then polished by use cloth and alumina having size $0.05 \mu \mathrm{m}$ then examined under optical microscope.

Double shear tested done to the brazed joints (three samples for each condition) for obtaining the shear force then the shear strength is determined by dividing this force on the actual brazed areas (two area) as shown in (equation 1) for obtaining the best conditions 
which will give the maximum shear strength. The die shown in (Figure-2) was used to hold the specimen between the jaws then force was applied using load rate $10 \mathrm{~N} / \mathrm{min}$. by universal tensile test machine type (ZWIK) having $1000 \mathrm{KN}$ maximum capacity.

The phase identification of the resulted joint interface that gives the maximum shear strength (one sample for each fillers) was examined by X-Ray diffraction using XRD6000 Shimadzu, philips-PW1840 difractometer machine. The samples used in this test should having $5 \mathrm{~mm}$ maximum thickness therefore the original samples after fractured machined to reach desired thickness then examine the interface and make evaluation of results.

$$
\text { Shear strength }=\frac{\text { Shear force }}{2 \mathrm{~A}} \cdots \cdots \cdots \cdot 1
$$

Where:

$\mathrm{A}=$ parallel surface area to shear force

\section{3- RESULTS AND DISCUSSION}

\section{3-1 Effect of soaking time on filler metal type AWS BCuP-1.}

\section{3-1-1 Double shear strength of brazed joint.}

The effect of soaking time on shear strength when using filler metal BCuP-1 was shown in (Figure-3). The occurrence of failure happened at interface region for all sample due to formation of excessive intermetallic compound or oxide film. First brazing joint gives shear strength $31 \mathrm{MPa}$ at soaking time $10 \mathrm{~min}$. this short time lead to insufficient diffuse of filler metal into the joint area, next when increasing this time to $20 \mathrm{~min}$. that is give increase in shear strength to $45 \mathrm{MPa}$ because of increase in wetting and spreading which lead to full penetration of filler metal in the joining area. When the holding time increase to $30 \mathrm{~min}$. the shear strength rise to $47 \mathrm{MPa}$ due to more interalloying (dissolution) of filler metal element with base metal and formation ductile solid solution and chemical compound (intermetallic compounds) types $\mathrm{Cu}_{3} \mathrm{P}, \mathrm{Fe}_{2} \mathrm{P}, \mathrm{Cu}_{5} \mathrm{Si}, \mathrm{AlCu}_{3}, \mathrm{CuO}, \mathrm{FeO}$ and $\alpha$-Fe on both surface of joint detected by X-Ray diffraction (Figure-4,5) that is responsible for joint strength. The up going in soaking time to $40 \mathrm{~min}$. lead to growth inermetallic compound and convert to brittle that caused declaim in shear strength to 39MPa. The phenomenon of continuous growth in these compound by absorbing each other and excessive dissolve of base metal into filler metal leads to decline in shear strength to $38 \mathrm{MPa}$ and $28 \mathrm{MPa}$ with soaking time $50 \mathrm{~min}$. and $60 \mathrm{~min}$. respectively.

\section{3-1-2 Microstructure of brazed joint.}

The microstructure of cross section area of brazed joint assemblies when using BCuP-1 filler metal at brazing temperature $940^{\circ} \mathrm{C}$ shown good wetting and spreading of this filler on 
both surface of steel and copper due to chemical effinity between them especially from copper side. The microstructures of joints at 10min. and 20min. soaking time (Figures-6, 7) respectively are shown clearly oxide film on interface between filler and base metals because of insufficient time of flux to remove this film and flow of filler metal .The increase of soaking time to 30min. (Figure-8) gives smooth joint and less oxide film with formation of intermetallic compound types $\left(\mathrm{Cu}_{3} \mathrm{P}\right.$ and $\left.\mathrm{CuO}\right)$ on copper interface and $\left(\mathrm{AlCu}_{3}, \mathrm{Cu}_{5} \mathrm{Si}, \alpha-\right.$ $\mathrm{Fe}, \mathrm{FeO}$, and $\mathrm{Fe}_{2} \mathrm{P}$ ) on steel interface that is detected by X-Ray diffraction (Figure-4, 5) respectively therefore the shear strength reached to beak value. The growth of this compound when brazing time rise to $40 \mathrm{~min}$. and $50 \mathrm{~min}$. shown in (Figure -9, 10) lead to make it brittle therefore the shear strength reduced. The long period at high temperature 60min. (Figure-11) will make the base metal dissolve into the filler metal excessively and changed to brittle columnar intermetallic compound that is lead to drop in shear strength.

\section{3-2 Effect of soaking time on filler metal type DIN L-Ag20Cd.}

\section{3-2-1 Double shear strength of brazed joint.}

The relationship between shear strength of joint and soaking time when using filler metal L-Ag20Cd shown in (Figure-12).From this curve we can notice that an increase in shear strength approximately doubled comparing with the filler metal BCuP-1. The soaking time at $10 \mathrm{~min}$. gives shear strength $71 \mathrm{MPa}$ and when rice the soaking time to $20 \mathrm{~min}$. these value up going to $88 \mathrm{MPa}$ and continues with soaking time $30 \mathrm{~min}$. and gives $98 \mathrm{MPa}$ because of formation solid solution and intermetallic compounds types $\mathrm{Cu}_{5} \mathrm{Si}, \mathrm{Fe}_{3} \mathrm{Zn}_{10}, \mathrm{FeZn}_{10}$, $\mathrm{Cu}_{5} \mathrm{Zn}_{6}, \mathrm{CuZn}, \mathrm{CdCu}_{2}, \mathrm{Cd}_{3} \mathrm{Cu}_{4}, \mathrm{Cd}_{3} \mathrm{Cu}, \mathrm{Cu}_{3} \mathrm{P}, \mathrm{CuO}, \mathrm{FeO}$, and $\alpha-\mathrm{Fe}$ reserved from X-Ray diffraction (Figure-13, 14) on both side of joint that is responsible on joint strength. Where the soaking time increase to $40 \mathrm{~min}$. leads to decline in shear strength to $67 \mathrm{MPa}$, the down going continues to $60 \mathrm{MPa}$ and $56 \mathrm{MPa}$ when the time increased to $50 \mathrm{~min}$, and $60 \mathrm{~min}$. respectively because of the excessive growth in the intermetallic compounds that is lead to make brittle joint.

\section{3-2-2 Microstructure of brazed joint.}

Use of $\mathrm{L}-\mathrm{Ag} 20 \mathrm{Cd}$ as filler metal at $790^{\circ} \mathrm{C}$ brazing temperature shown excellent chemical effinity with both base metals lead to increase wetting and spreading process when it is compared with BCuP-1 filler metal. The high content of $\mathrm{Cu}, \mathrm{Zn}, \mathrm{Ag}$, and $\mathrm{Cd}$ in this filler leads to formation of a solid solution and multiple types of intermetallic compound which strengthening the joint. This can be seen clearly from the cross section area of brazed joint for all soaking time. (Figure-15, 16) shown the microstructure at soaking time 10min. and 20min. respectively at these time there is a little amount of oxide with dissolution of base metals into filler, then when time 30min. (Figure-17) the growth of compound types $\mathrm{Cu}_{5} \mathrm{Zn}_{6}, \mathrm{CuZn}$, 
$\mathrm{CdCu}_{2}, \mathrm{Cd}_{3} \mathrm{Cu}_{4}, \mathrm{Cd}_{3} \mathrm{Cu}, \mathrm{CuO}$, and $\mathrm{Cu}_{3} \mathrm{P}$ on copper interface and $\mathrm{Cu}_{5} \mathrm{Si}, \mathrm{Fe}_{3} \mathrm{Zn}_{10}, \mathrm{FeZn}_{10}, \mathrm{FeO}$, and $\alpha$-Fe on steel interface that is detected by X-Ray diffraction (Figure-13, 14) respectively, and the grain take equiaxis shape. The increase of soaking time to $40 \mathrm{~min}$. and $50 \mathrm{~min}$ leads to increase in intermetallic compound growth (Figure-18,19) respectively and this growth continuous when time reach to 60min.(Figure-20) and the grain change to brittle dentartic shape.

\section{CONCLUSIONS:}

1. Furnace brazing can be used to join dissimilar metals, copper type ISO C10300 to silicon steel type ASTM 36F145 by using filler metals DIN L-Ag 20 Cd and AWS BCuP-1

2. Maximum double shear strength was obtained with filler metal type DIN LAg20Cd reached to $98 \mathrm{MPa}$.

3. Maximum double shear strength was $47 \mathrm{MPa}$ obtained when using filler metal type AWSBCuP-1

4. The best soaking time at brazing temperature was $30 \mathrm{~min}$. for both fillers.

\section{REFERENCES}

1. Nasiri A. M., Lil, Kims. H., Zhou Y., Weckman D. C., Nguyen T. C. (2011)."Microstructure and Properties of Laser Brazed Magnesium to Coated Steel", Welding Journal, Vol.90, pp. 211s-219s.

2. Weman K., (2003), "Welding Processes Handbook", First published, Cambridge England, Woodhead Publishing Ltd, pp. 129-131.

3. ASM Handbook, (1993), "Welding, Brazing, and Soldering", Second edition, United States of America, Vol.6, pp. 911-948.

4. Robert W. M., (2004), "Joining of Materials and Structures", First published, the United States of America, Elsevier Butterworth-Heinemann, pp.349-387.

5. Karamıs M.B., Tasdemirci A., Nair F., (2003), "Microstructural Analysis and Discontinuities in the Brazed Zone of Copper Tubes", Journal of Materials Processing Technology, Vol. 141, pp.302-312.

6. Flom Y., Wang L., (2004), "Flaw Tolerance in Lap Shear Brazed Joints — Part 1", Welding Journal, January, pp.32-38.

7. Liu L., Wang S., Zhao L., (2008), "Study on the dissimilar magnesium alloy and copper lap joint by TIG welding", Materials Science and Engineering Elsevier, Volume 476, Issues 1-2, pp.206-209. 
8. Oztoprak B. G. , Akman E. , Hanon M.M. ,(2013), "Laser welding of copper with stellite 6 powder and investigation using LIBS technique", Optics \& Laser Technology Elsevier, Volume 45, pp.748-755

9. ASM Handbook, (1990), "Properties and selection nonferrous alloy and special purpose material", tenth edition, United States of America, ASM International Handbook Committee, Vol.2, pp.911-948.

10. Sigler D. R., Schroth J. G., Wang Y., (2007), "Sulfide-Induced Corrosion of CopperSilver-Phosphorus Brazed Joints in Welding Transformers", Welding Journal, Vol.86, pp. 340-348.

11. Nasiri A. M., Weckman D. C., Zhou Y. ,(2013), "Interfacial Microstructure of Diode Laser Brazed AZ31B Magnesium to Steel Sheet Using a Nickel Interlayer", Welding Journal, Vol. 92, pp.1-10.

12. Elrefaey A., Wojarski L., Pfeiffer J., (2013), "Preliminary Investigation on UltrasonicAssisted Brazing of Titanium and Titanium/Stainless Steel Joints", Welding Journal, Vol. 92. pp. 148-153.

13. ASTM A677M-98a, (1999), "Standard Specification for Nonoriented Electrical Steel, Fully Processed Types".

14. AWS committee on brazing and soldering, (2002), "Brazing Hand book". American Welding Society. Miami, Florida. Fourth Edition, pp. pp.47-56.

15. ASME Boiler and Pressure Vessel Code, (1989),"Welding Roads, Electrodes, and Filler Metal", the American Society of Mechanical Engineers, Section II Part C. pp.127-145.

Table (1): Chemical composition of copper ${ }^{[9]}$.

\begin{tabular}{|c|c|c|}
\hline Chemical Composition of Copper ISO C10300 & $\% \mathrm{Cu}$ & $\% \mathrm{P}$ \\
\hline Nominal & 99.95 & 0.003 \\
\hline Actual & 99.98 & 0.002 \\
\hline
\end{tabular}


Table (2): Chemical composition of silicon steel ${ }^{[13]}$.

\begin{tabular}{|c|c|c|c|c|c|}
\hline $\begin{array}{c}\text { Chemical Composition Of } \\
\text { Silicon Steel ASTM 36F145 }\end{array}$ & $\% \mathrm{C}$ & $\% \mathrm{Si}$ & $\% \mathrm{Mn}$ & $\% \mathrm{Al}$ & $\% \mathrm{Fe}$ \\
\hline Nominal & $0.12-0.17$ & $1.5-2.25$ & $0.19-0.8$ & 0.4 & Balance \\
\hline Actual & 0.15 & 1.8 & 0.21 & 0.3 & Balance \\
\hline
\end{tabular}

Table (3): Chemical composition of filler metals ${ }^{[14,15]}$.

\begin{tabular}{|c|c|c|c|c|c|}
\hline Chemical Composition of filler metal & $\% \mathrm{Cu}$ & $\% \mathrm{Ag}$ & $\% \mathrm{Zn}$ & $\% \mathrm{Cd}$ & $\% \mathrm{P}$ \\
\hline DIN L-Ag20Cd & 41 & 17 & 26 & 16 & - \\
\hline AWS BCuP-1 & 95 & - & - & - & 5.0 \\
\hline
\end{tabular}

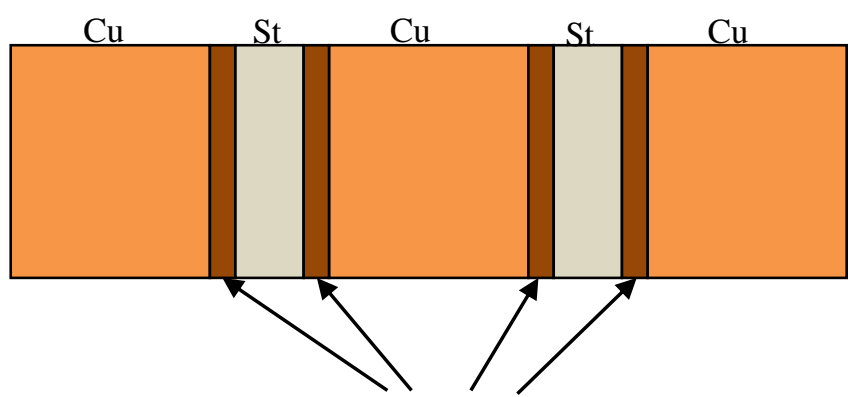

Filler metal

Fig. (1): Assembly of brazing sample.

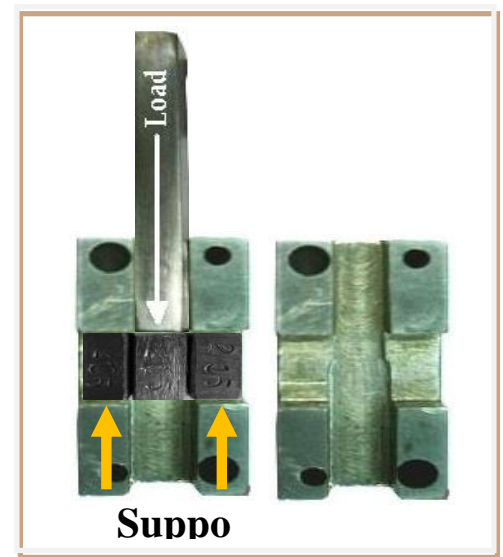

Fig. (2): Double shear die. 


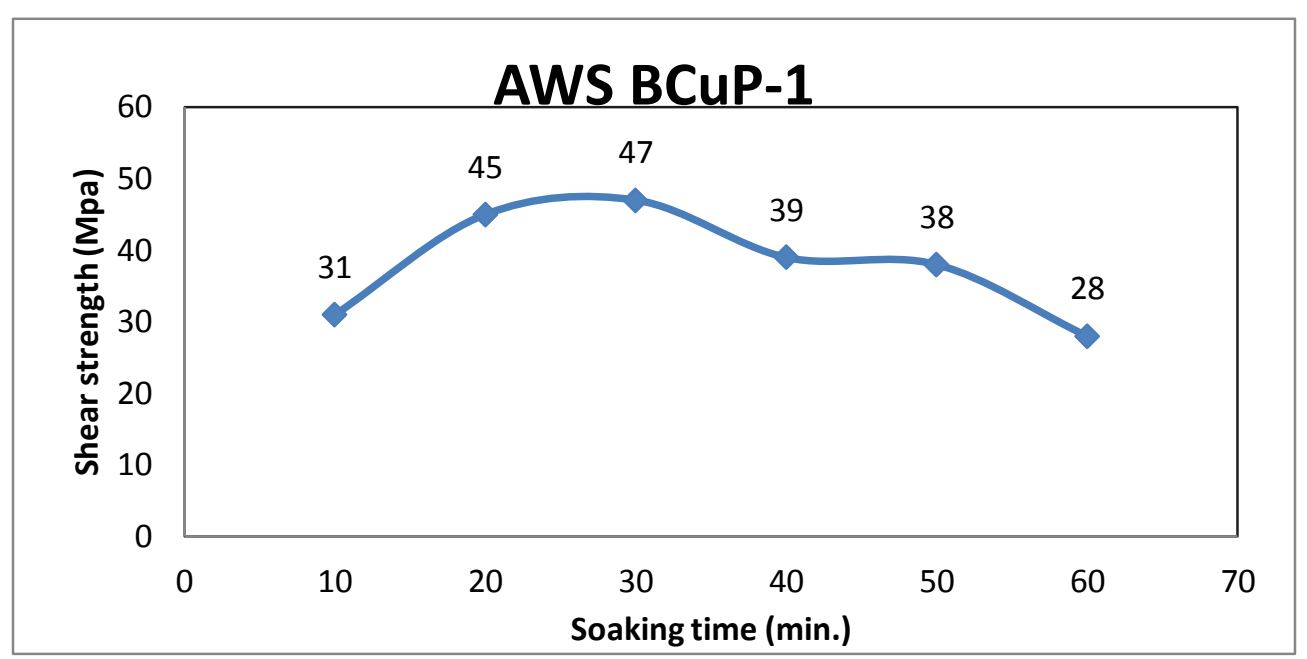

Fig. (3): Effect of soaking time on shear strength of joint using filler AWS BCuP-1.

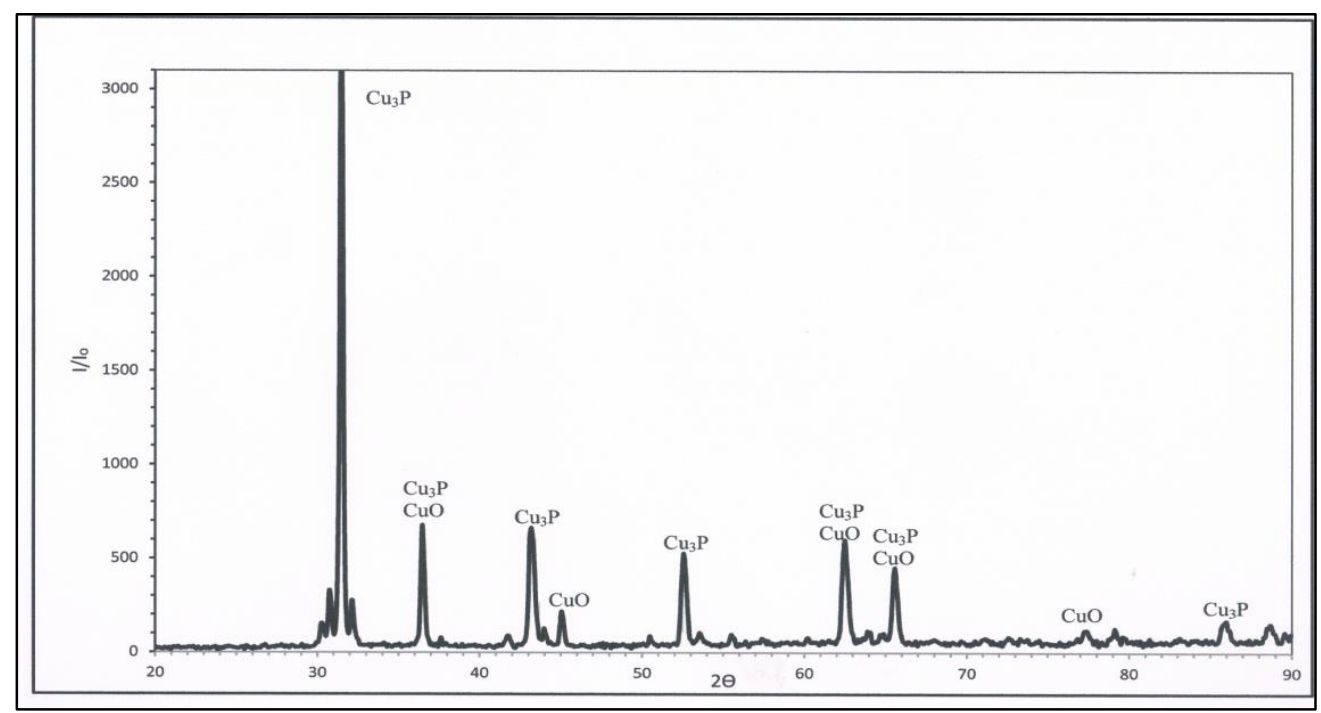

Fig. (4): X-Ray diffraction for $\mathrm{Cu}$ side brazed by BCuP-1 filler metal at soaking time30 min.

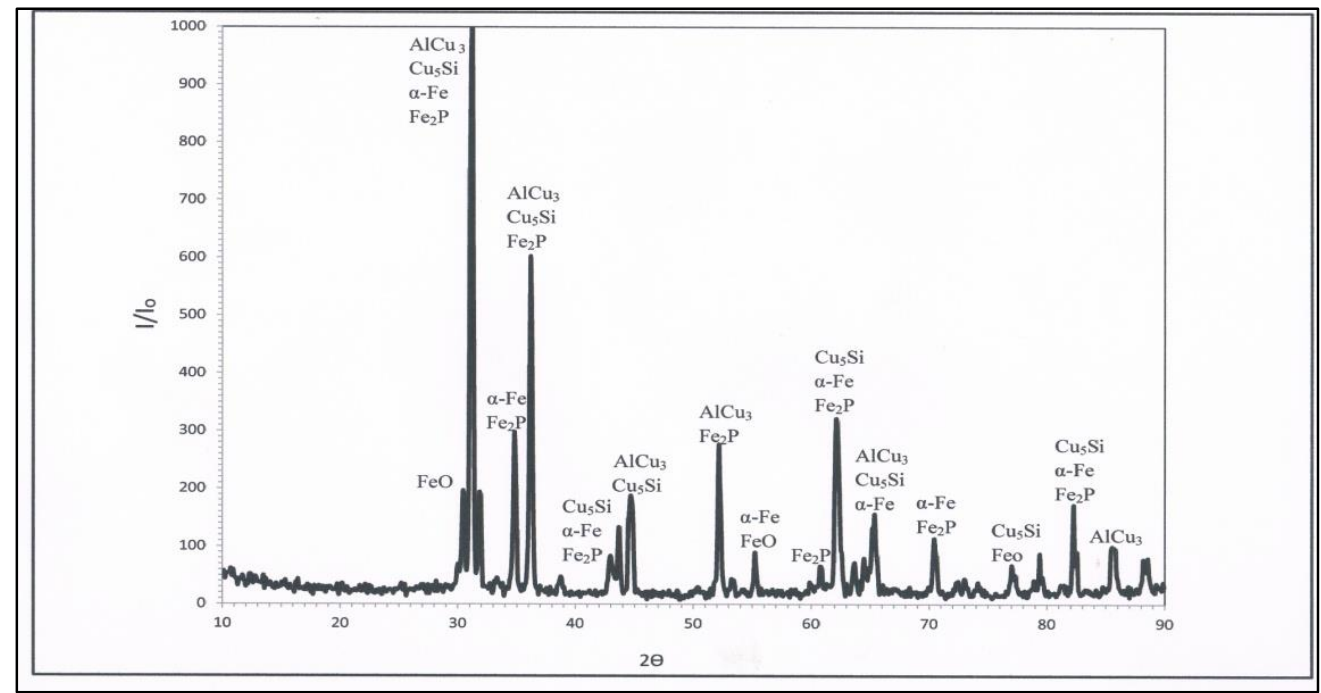

Fig. (5): X-Ray diffraction for st. side brazed by BCuP-1 filler metal at soaking time $30 \mathrm{~min}$. 


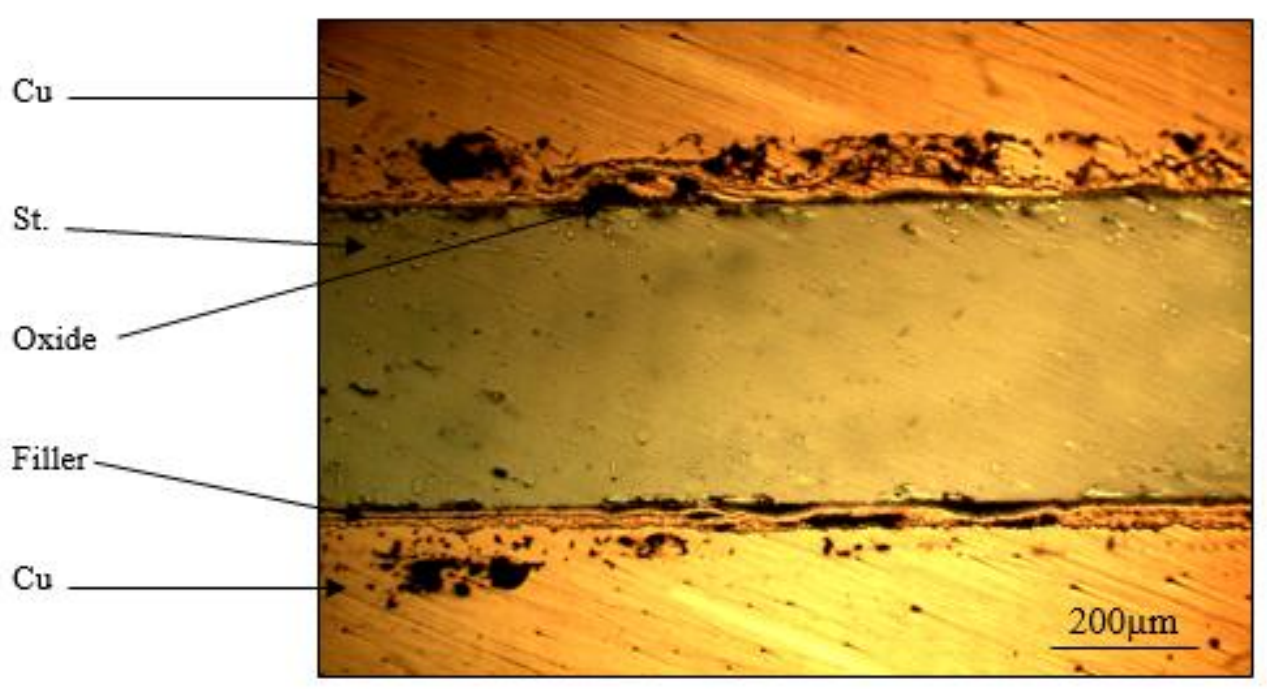

Fig. (6): Microstructure of joint using filler AWS BCuP-1 and soaking time $10 \mathrm{~min}$.

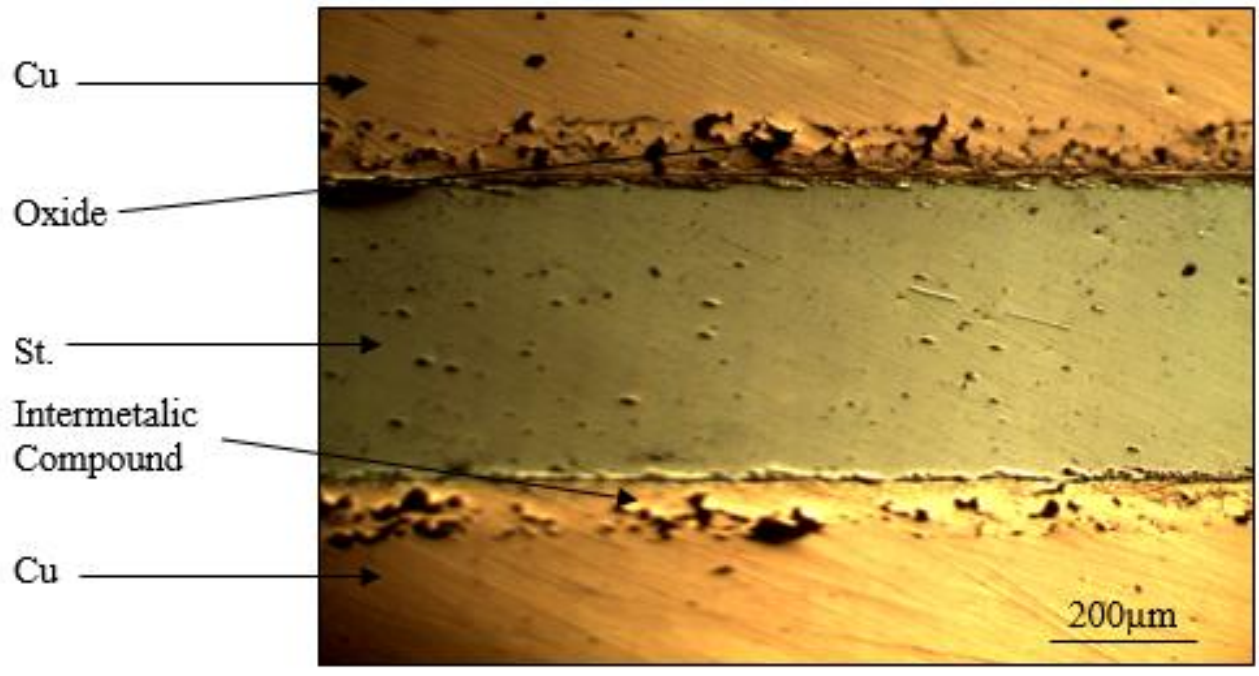

Fig. (7): Microstructure of joint using filler AWS BCuP-1 and soaking time $20 \mathrm{~min}$.

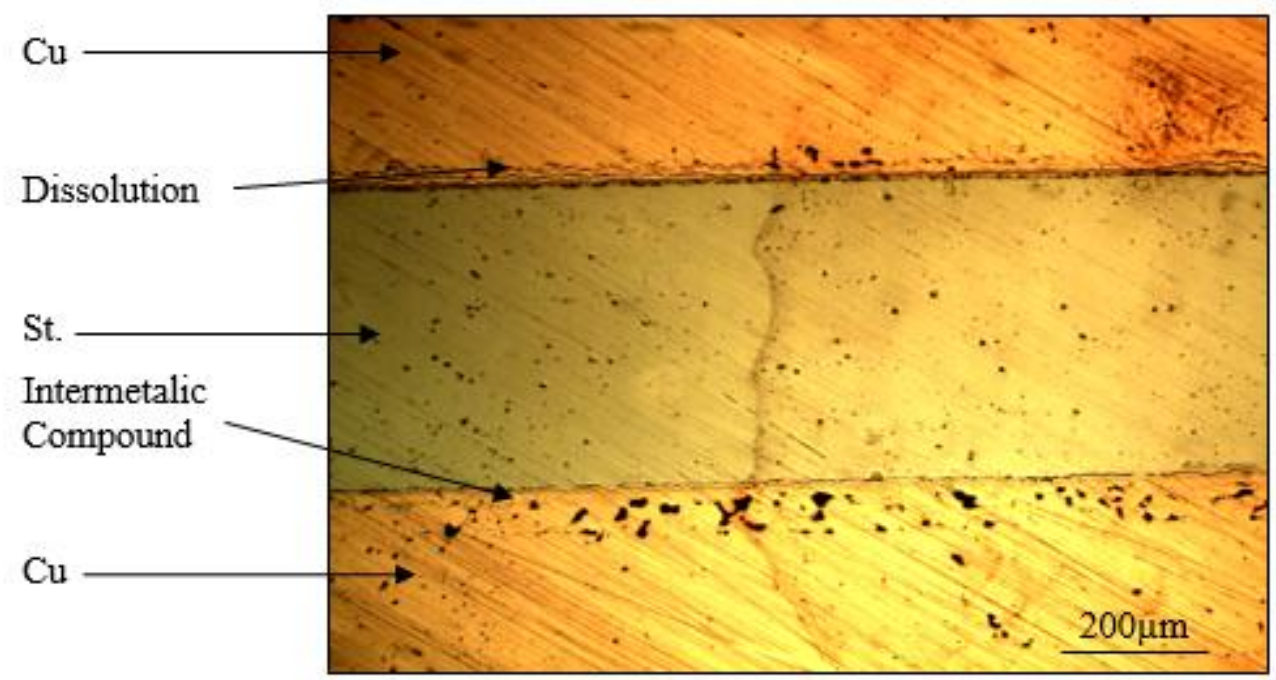

Fig. (8): Microstructure of joint using filler AWS BCuP-1 and soaking time $30 \mathrm{~min}$. 


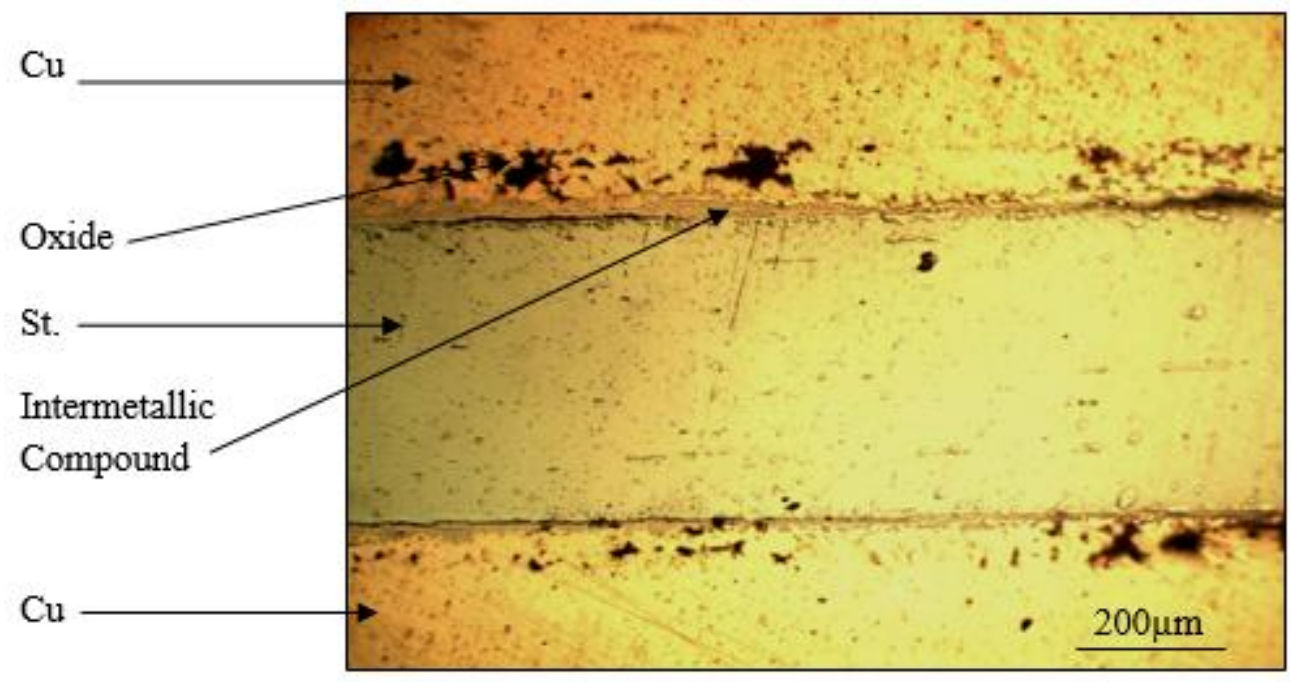

Fig. (9): Microstructure of joint using filler AWS BCuP-1 and soaking time 40 min.

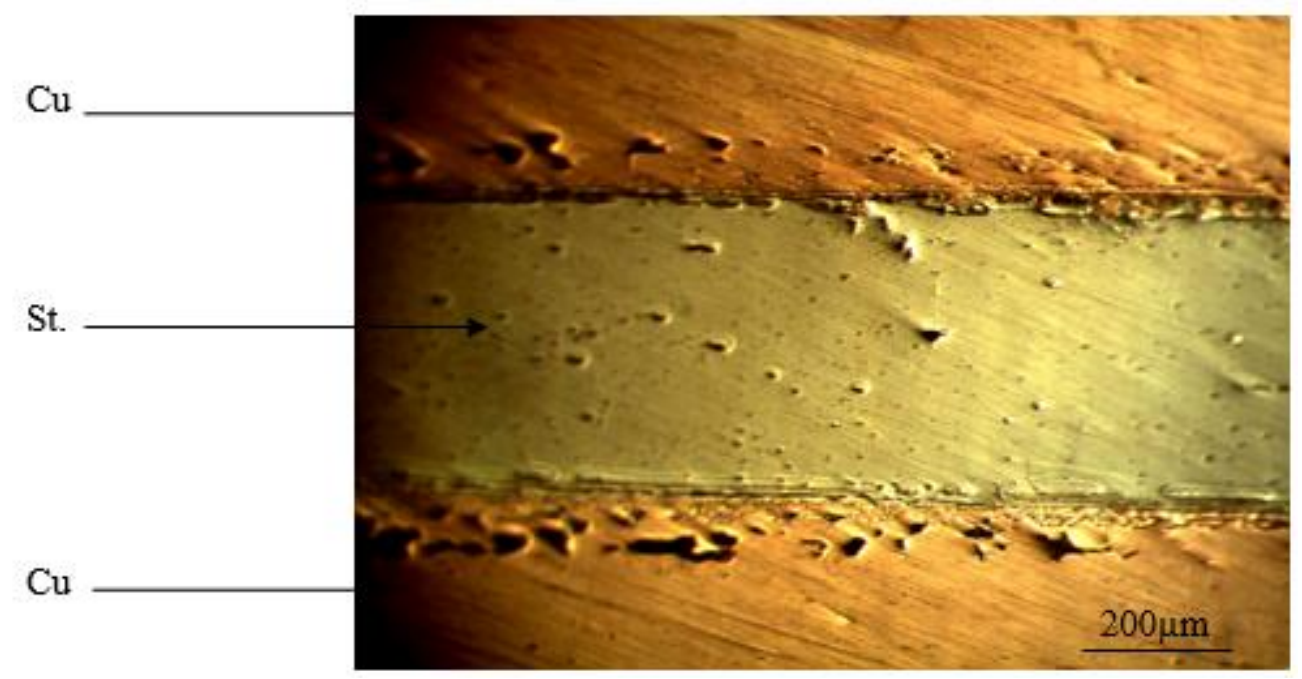

Fig. (10): Microstructure of joint using filler AWS BCuP-1 and soaking time $50 \mathrm{~min}$.

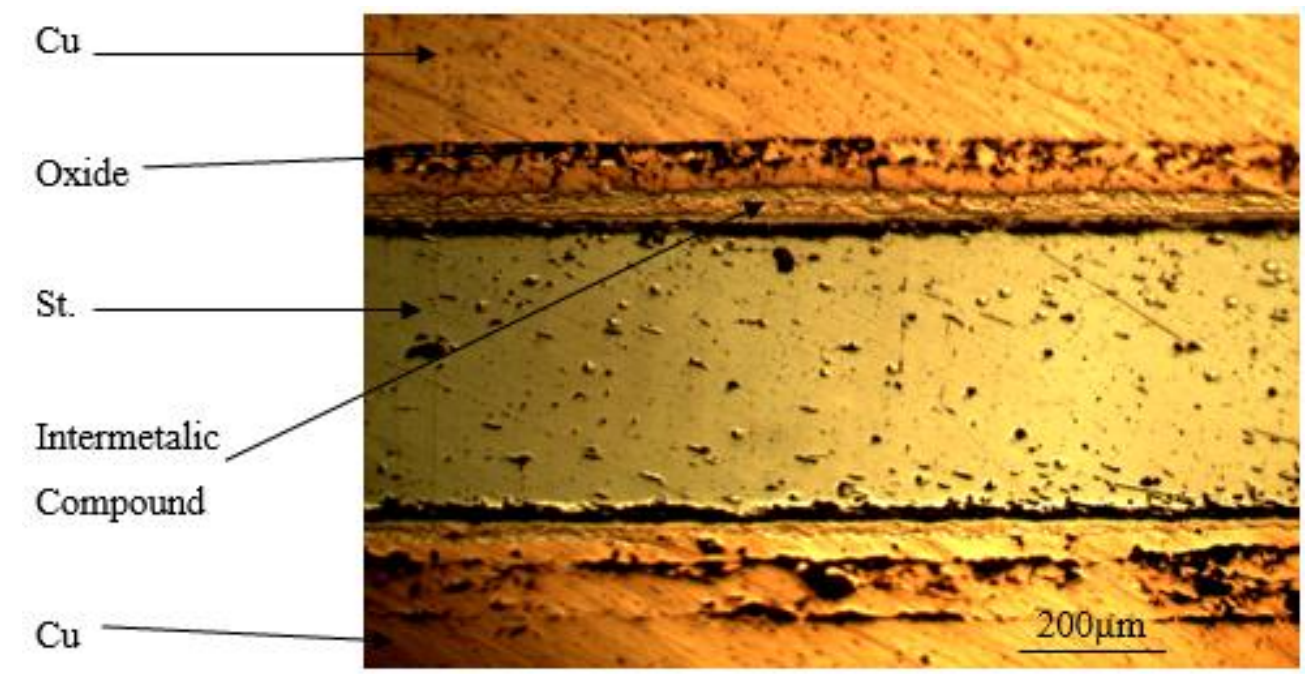

Fig. (11): Microstructure of joint using filler AWS BCuP-1 and soaking time 60 min. 


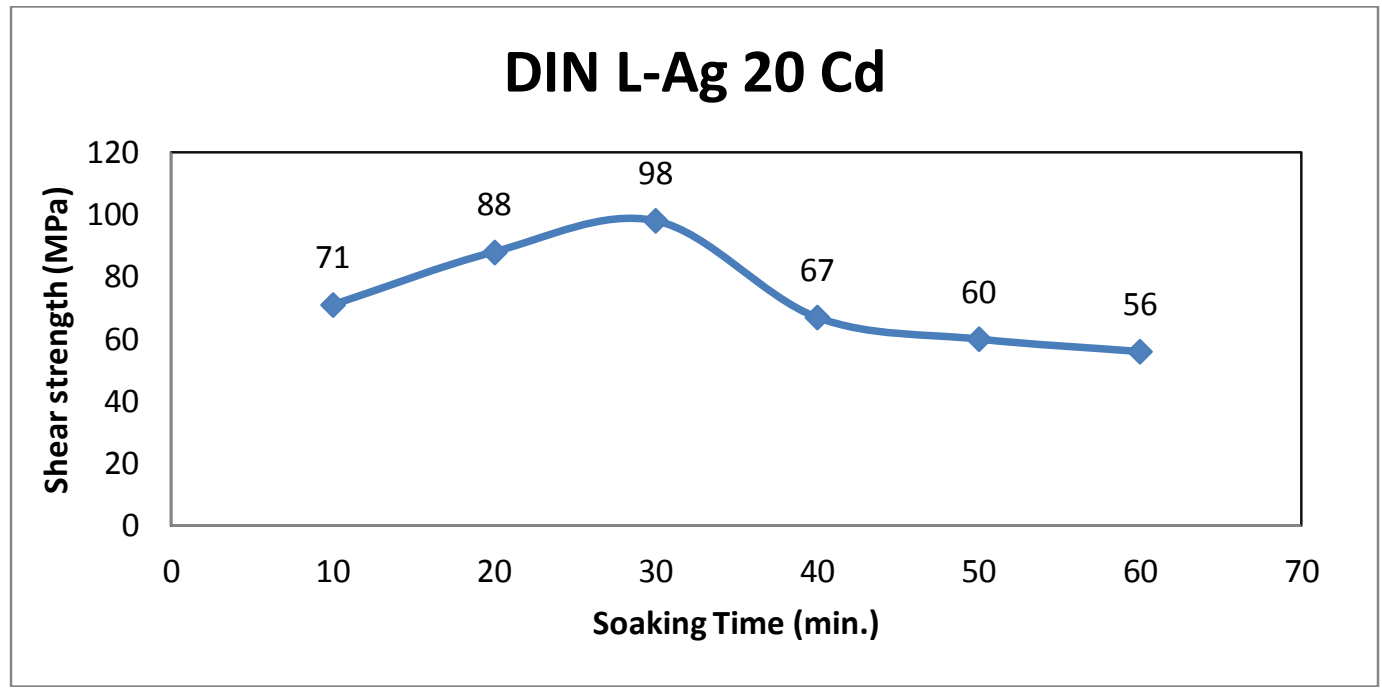

Fig. (12): Effect of soaking time on shear strength of joint using filler DIN L-Ag20Cd.

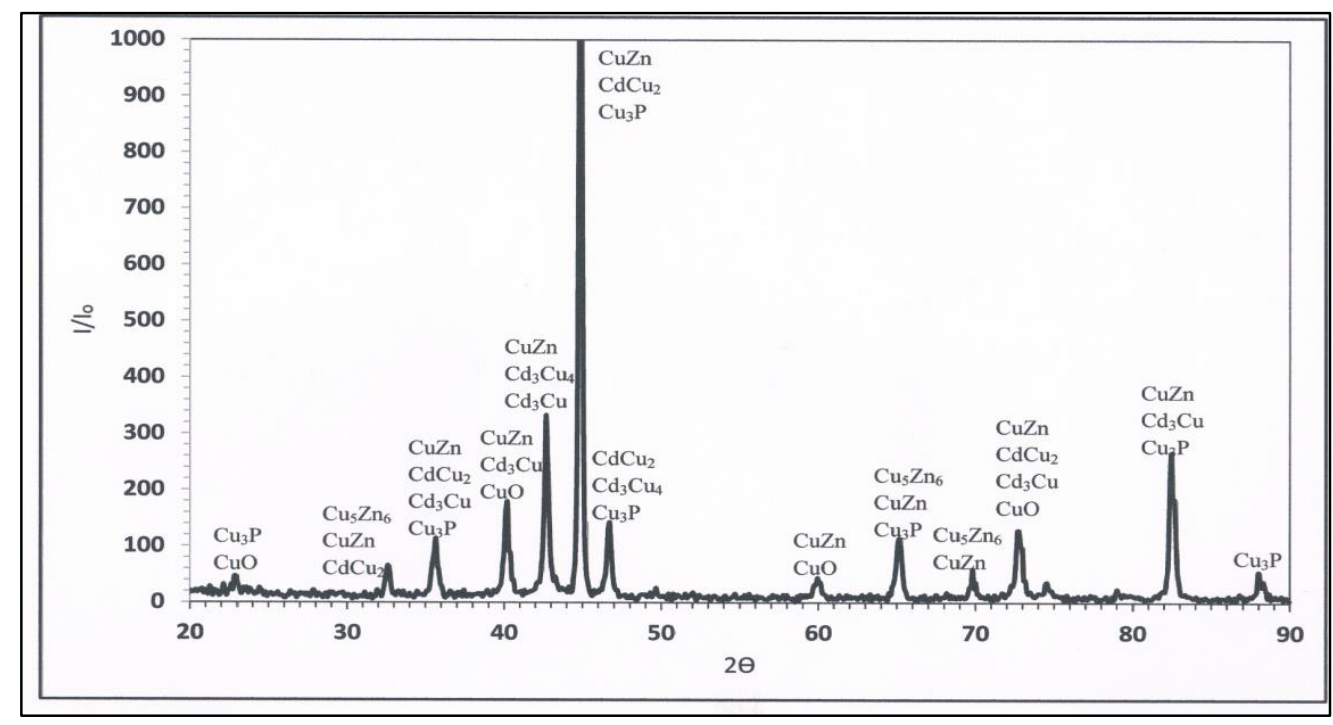

Fig. (13): X-Ray diffraction for $\mathrm{Cu}$ side brazed by $\mathrm{L}-\mathrm{Ag} 20 \mathrm{Cd}$ filler metal at soaking time30 min.

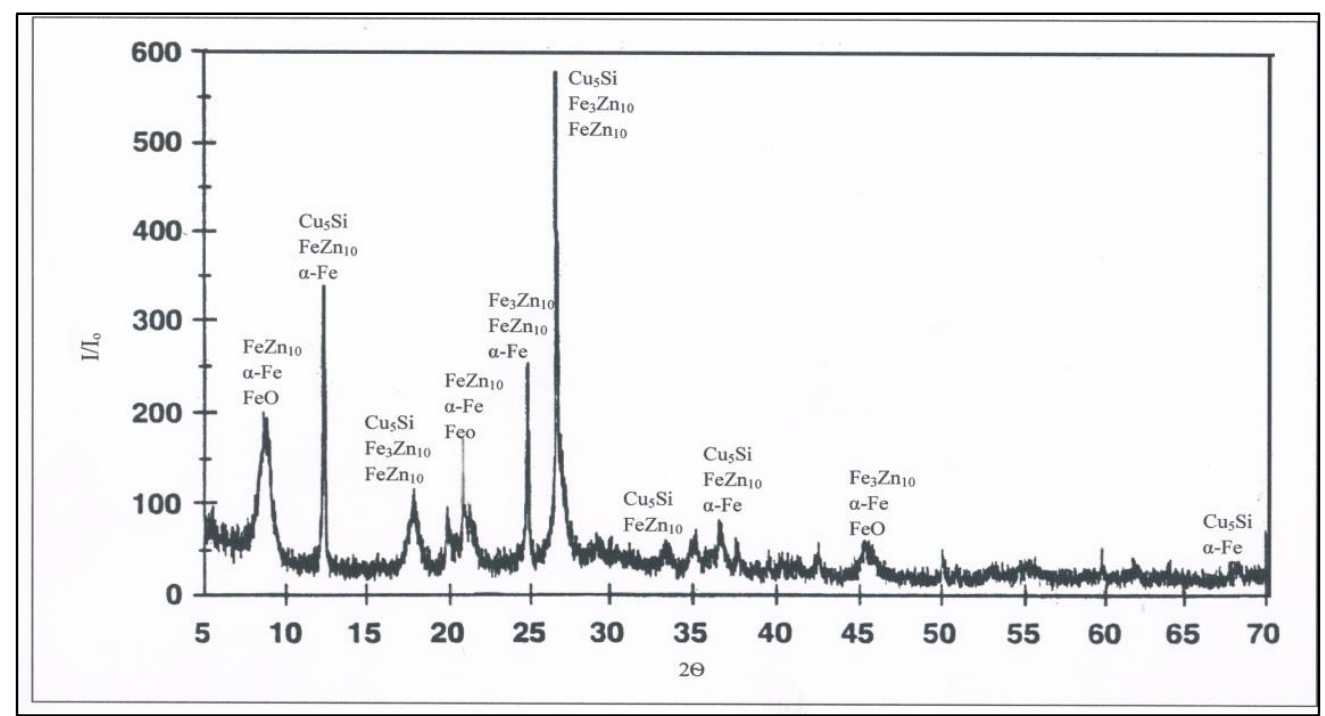

Fig. (14): X-Ray diffraction for st. side brazed by L-Ag20Cd filler metal at soaking time $30 \mathrm{~min}$. 


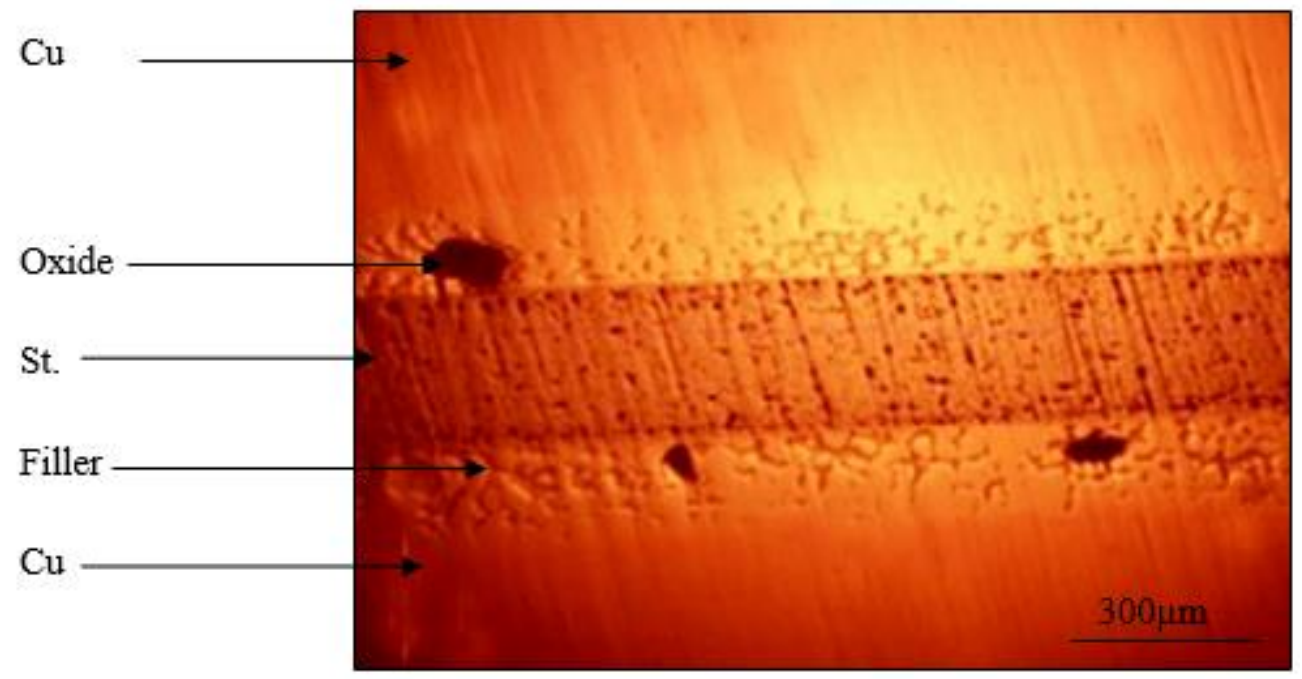

Fig. (15): Microstructure of joint using filler DIN L-Ag20Cd and soaking time $10 \mathrm{~min}$.

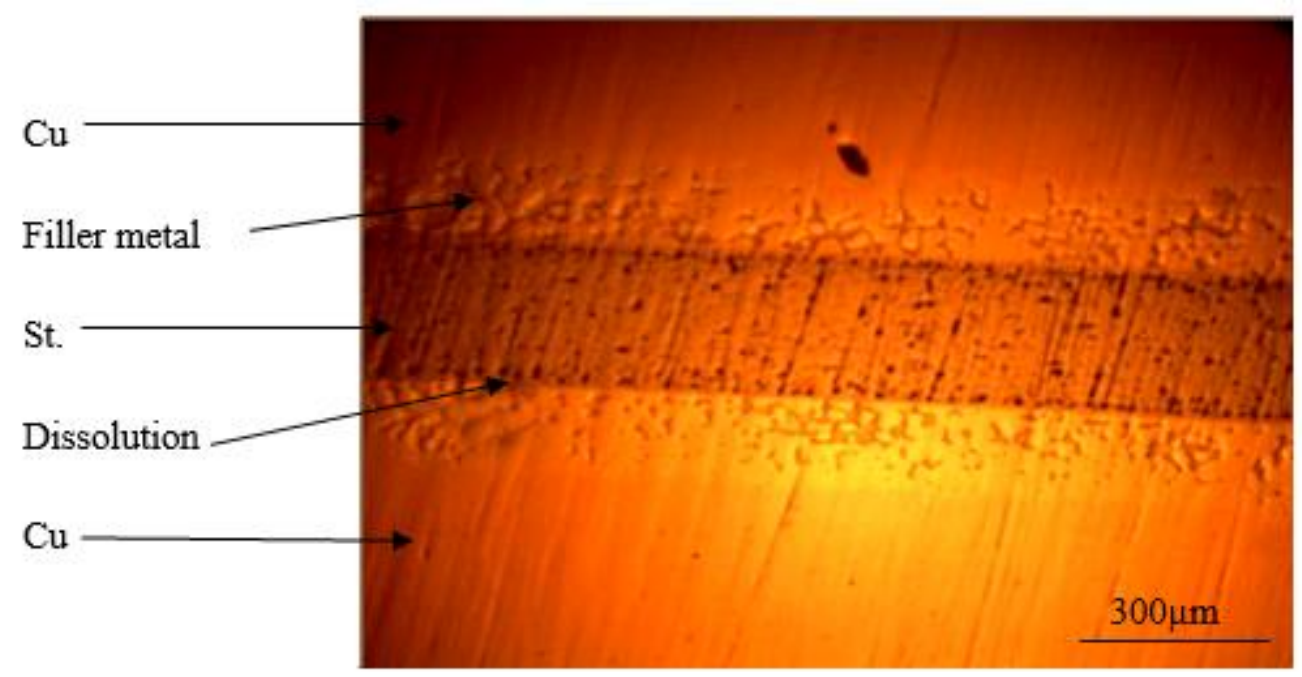

Fig. (16): Microstructure of joint using filler DIN L-Ag20Cd and soaking time $20 \mathrm{~min}$.

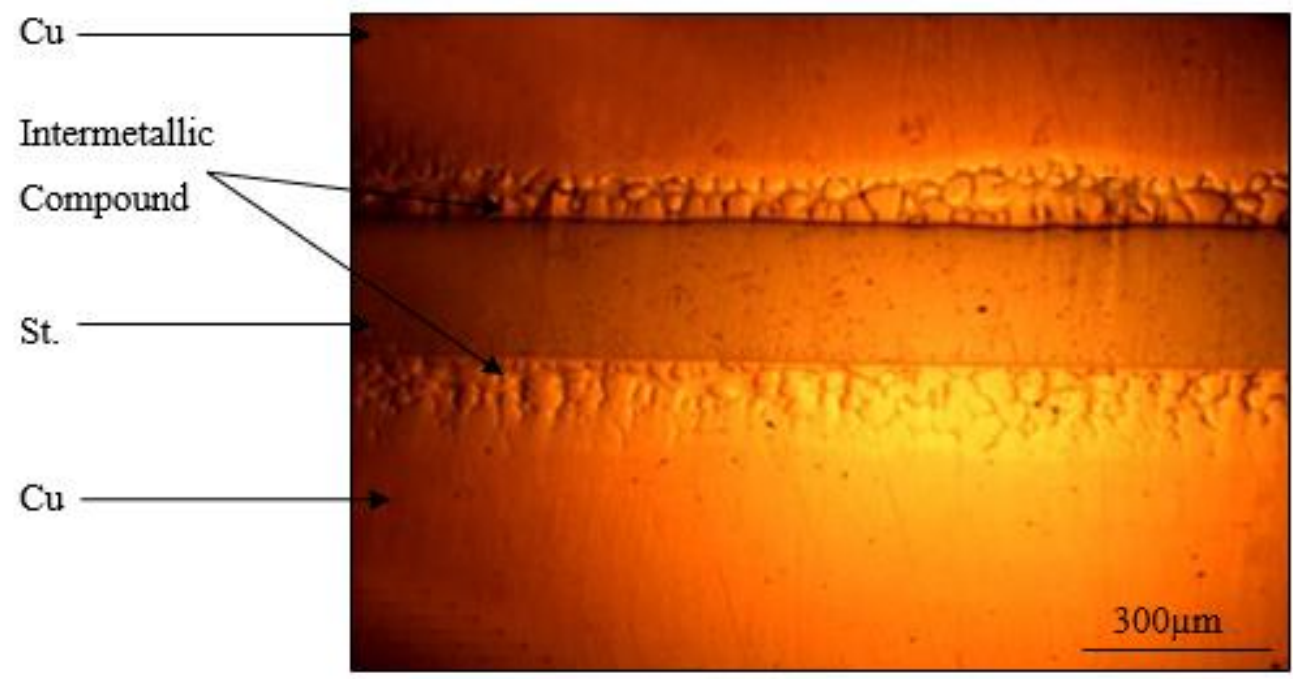

Fig. (17): Microstructure of joint using filler DIN L-Ag20Cd at soaking time $30 \mathrm{~min}$. 


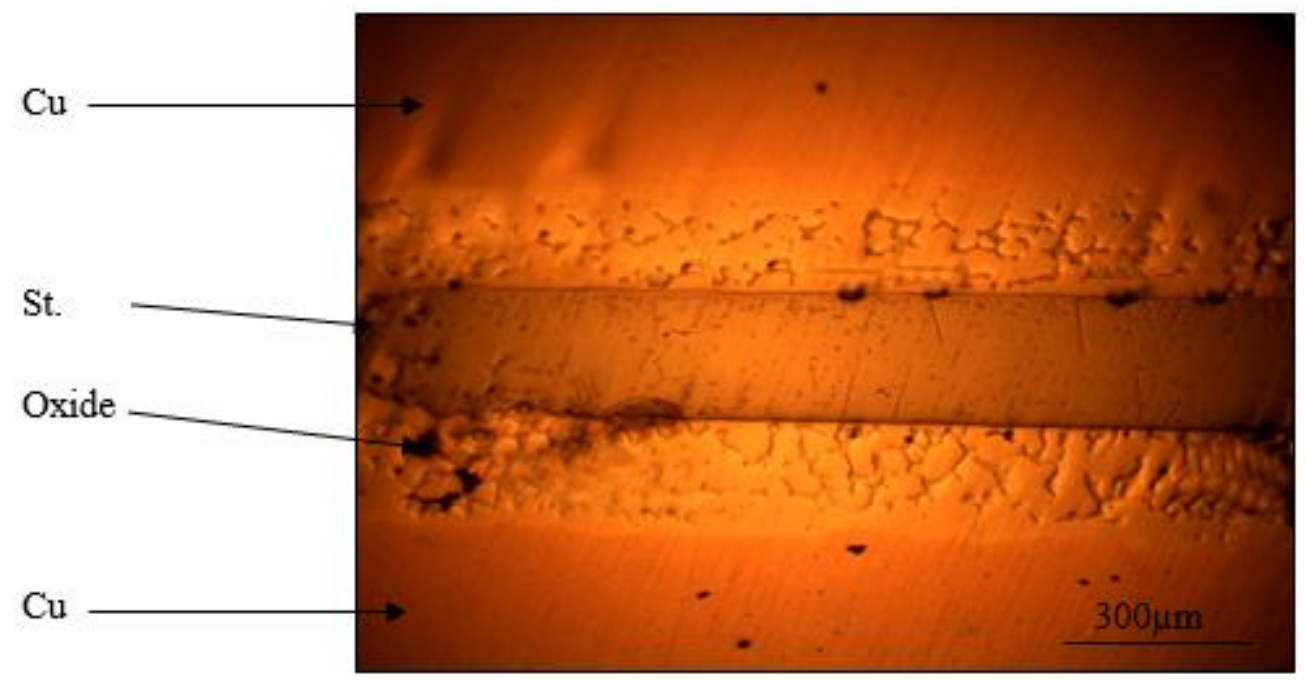

Fig. (18): Microstructure of joint using filler DIN L-Ag20Cd and soaking time $40 \mathrm{~min}$.

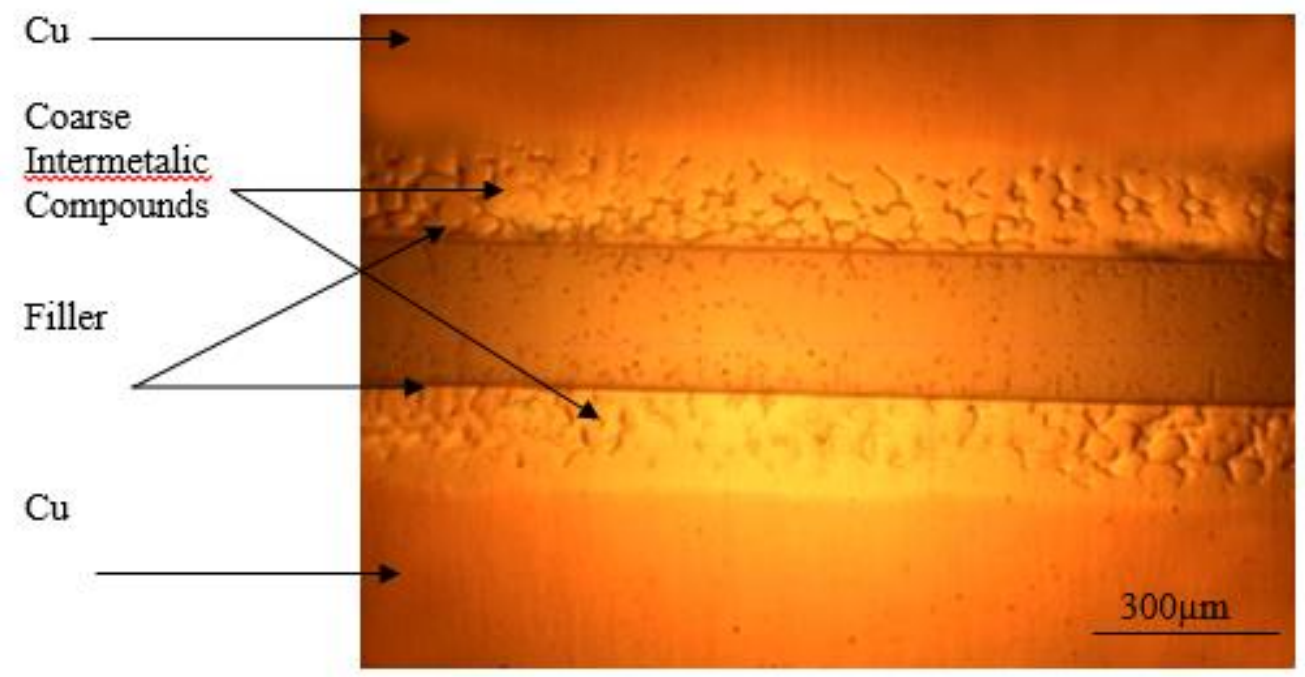

Fig. (19): Microstructure of joint using filler DIN L-Ag20Cd and soaking time $50 \mathrm{~min}$.

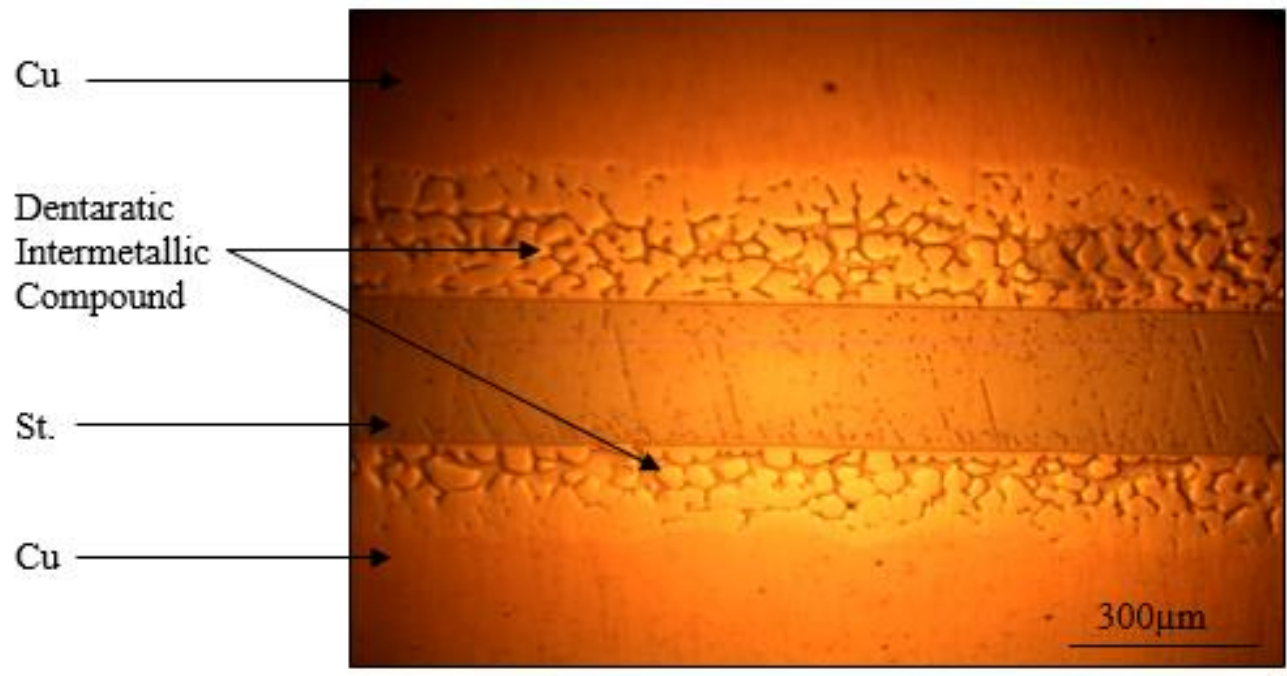

Fig. (20): Microstructure of joint using filler DIN L-Ag20Cd and soaking time $60 \mathrm{~min}$. 


\section{اللحام بطريقة المونة بواسطة الفرن للنحاس عالي الموصلية خالي الاوكسجين مع الفولاذ السليكوني \\ عمر سعد صالح \\ مدرس مساعد / الكلية الثنتية- بغداد}

الخلاصة:

اجريت عملية الربط بالمونة بواسطة الفرن لانتاج وصلة ربط بين معدنين مختلفين، هما النحاس عالي الموصلية

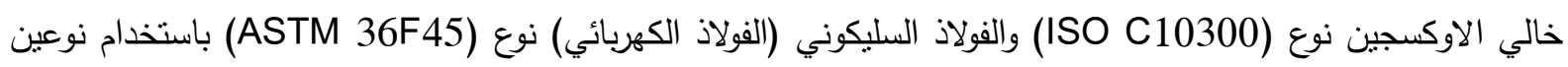

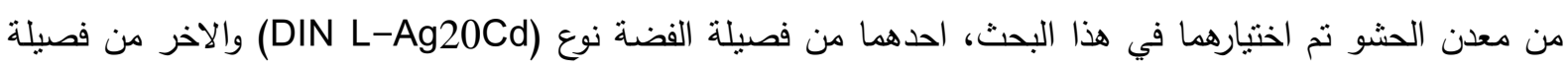

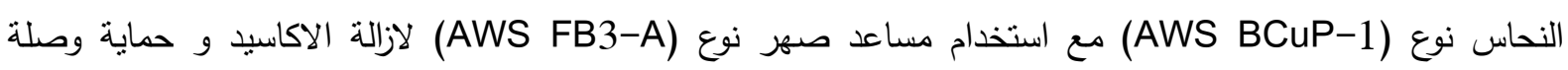
اللحام.

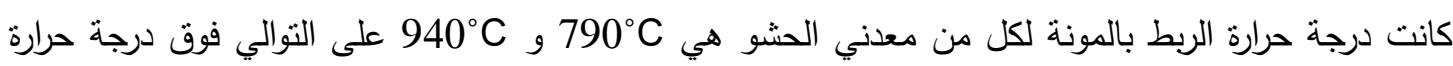

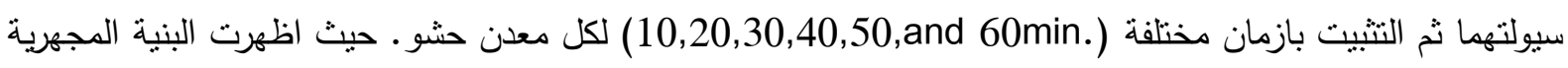

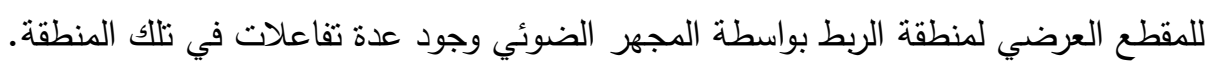

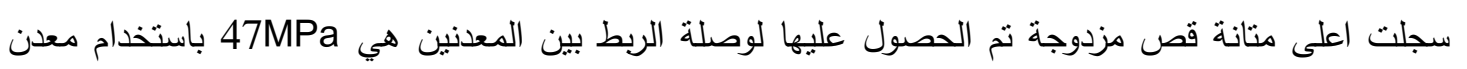

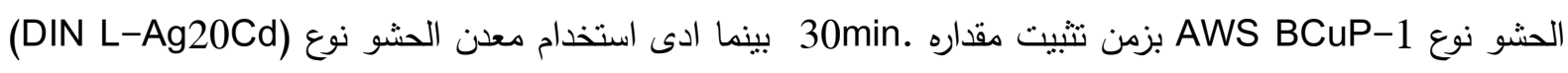

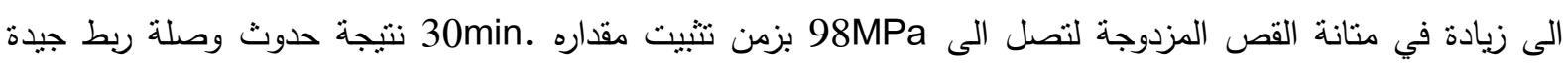

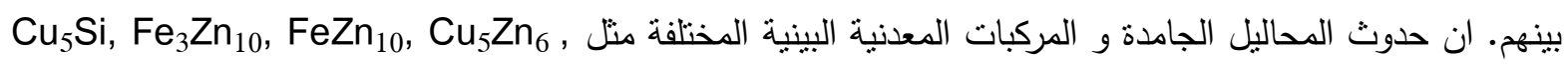
كuZn, CdCu $, \mathrm{Cd}_{3} \mathrm{Cd}_{4}, \mathrm{Cd}_{3} \mathrm{Cu}, \mathrm{Cu}_{3} \mathrm{P}, \alpha-\mathrm{Fe}$ فحص الحيود بالاثعة السينية. 